\title{
Culture-independent analysis of bacterial communities in hemolymph of American lobsters with epizootic shell disease
}

\author{
Robert A. Quinn ${ }^{1}$, Roxanna Smolowitz ${ }^{2}$, Andrei Y. Chistoserdov ${ }^{1, *}$ \\ ${ }^{1}$ Department of Biology University of Louisiana at Lafayette, Lafayette, Louisiana 70504, USA \\ ${ }^{2}$ Department of Biology and Marine Biology, Roger Williams University, Bristol, Rhode Island 02809, USA
}

\begin{abstract}
Epizootic shell disease (ESD) of the American lobster Homarus americanus H. Milne Edwards, 1837 is a disease of the carapace that presents grossly as large, melanized, irregularly shaped lesions, making the lobsters virtually unmarketable because of their grotesque appearance. We analyzed the bacterial communities present in the hemolymph of lobsters with and without ESD using nested-PCR of the 16S rRNA genes followed by denaturing gradient gel electrophoresis. All lobsters tested $(\mathrm{n}=42)$ had bacterial communities in their hemolymph, and the community profiles were highly similar regardless of the sampling location or disease state. A number of bacteria were detected in a high proportion of samples and from numerous locations, including a Sediminibacterium sp. closely related to a symbiont of Tetraponera ants (38/42) and a Ralstonia sp. (27/42). Other bacteria commonly encountered included various Bacteroidetes, Pelomonas aquatica, and a Novosphingobium sp. One bacterium, a different Sediminibacterium sp., was detected in $20 \%$ of diseased animals $(n=29)$, but not in the lobsters without signs of ESD $(\mathrm{n}=13)$. The bacteria in hemolymph were not the same as those known to be present in lesion communities except for the detection of a Thalassobius sp. in 1 individual. This work demonstrates that hemolymph bacteremia and the particular bacterial species present do not correlate with the incidence of ESD, providing further evidence that microbiologically, ESD is a strictly cuticular disease. Furthermore, the high incidence of the same species of bacteria in hemolymph of lobsters may indicate that they have a positive role in lobster fitness, rather than in disease, and further investigation of the role of bacteria in lobster hemolymph is required.
\end{abstract}

KEY WORDS: Sediminibacterium - Denaturing gradient gel electrophoresis · DGGE - Bacterial community $\cdot$ Symbiont $\cdot$ Homarus americanus

\section{INTRODUCTION}

Beginning in the late 1990s, a new form of shell disease of the American lobster Homarus americanus $\mathrm{H}$. Milne Edwards, 1837, termed epizootic shell disease (ESD), was described on the North Atlantic coast of North America (Castro \& Angell 2000). Lobsters with this disease will often survive by mounting both a passive and active inflammatory response characterized by melanization of the carapace, localized pro- duction of inflammatory membranes separating the cuticular epithelium from the eroded cuticle, and/or infiltration of hemocytes into the area between the eroded cuticle and the cuticular epithelium (Smolowitz et al. 2005) or in some cases, by 'molting out' of the disease (Smolowitz et al. 2005); however, they are mostly unmarketable due to the grotesque appearance of the shell lesions. ESD is characterized by severe deep erosions of the cephalothorax and the abdomen that extend laterally and, unlike the other 
known forms of shell disease, irregularly over the dorsal carapace of the animal (Smolowitz et al. 2005). The disease has been observed in 20 to $30 \%$ of wild lobster populations from southern New England (Castro \& Angell 2000, Cobb \& Castro 2006).

An established facet of the disease is the involvement of bacteria in the formation of the lesions. Thus, the microbial community of the lesion material has been described by culture on various microbiological media (Chistoserdov et al. 2002, 2005) and with culture-independent techniques (Chistoserdov et al. 2012). The community is primarily bacterial, with members of the Flavobacteriaceae and Alphaand Gammaproteobacteria detected by cultureindependent techniques, and Aquimarina spp., Pseudoalteromonas gracilis, Shewanella spp., Vibrio spp., Pseudoaltermonas spp., and Alteromonas arctica detected by culture-based methods (Chistoserdov et al. 2005). The enzymatic activities of these bacteria on the lipid, protein, and chitin component of the lobster carapace are believed to be involved in the formation of the lesions, and 2 specific bacteria, viz. Aquimarina 'homaria' and a Thalassobius sp., are the primary pathogens (Quinn et al. 2012).

Bartlett et al. (2008) investigated the presence of bacteremia in hemolymph of the American lobster, in an attempt to associate bacteremia with certain environmental factors and also the presence of ESD. While various bacterial species were cultured from hemolymph of some lobsters, their presence did not correlate with ESD. Chistoserdov et al. (2005) conducted a similar study and found mostly seafood spoilage bacteria (2 Pseudomonas sp. and Brochothrix thermosphacta), but no correlation between ESD occurrence and bacterial presence in hemolymph was observed. These 2 studies indicate that ESD is not reflected in the internal microbial communities of afflicted lobsters and that no culturable pathogen has yet been identified or isolated from hemolymph. The work reported here is a continued investigation of the bacterial community of the American lobster hemolymph with and without ESD in an attempt to associate specific species with any diseased state. Our method involved PCR amplification of the bacterial 16S rRNA genes followed by denaturing gradient gel electrophoresis (PCR-DGGE). Originally applied to microbiology by Muyzer et al. (1993), this technique is a powerful tool for analyzing the diversity of microbial communities in natural samples. By amplifying the 16S rRNA genes of all bacteria present using universal primers and separation of the sequence variants in the denaturing gradient gel, the sequences of individual bands can then be compared to available databases for identification of strains or species (reviewed by Muyzer et al. 1998). This technique is culture-independent and can identify bacteria present in lobster hemolymph that may have been missed due to the limitations of culture on agar media.

\section{MATERIALS AND METHODS}

\section{Lobster collection, hemolymph sampling, and DNA extraction}

A total of 42 lobsters (29 diseased and 13 without signs of shell disease) were collected from 9 different sites between 2003 and 2008 and sent to our laboratory by courier as live animals. The locations of lobster sampling and health status are summarized in Table 1. Any deceased lobsters were left out of the analysis. Health status as diseased or healthy was determined by visual observation of ESD lesions, as described by Cobb \& Castro (2006). The lobsters not showing visible symptoms of ESD are herein referred to as ESD-free, but may have been diseased in other respects. Live lobsters were gently rinsed with sterile

Table 1. Homarus americanus. Source and disease status of lobster hemolymph samples analyzed in this study. ESD: epizootic shell disease

\begin{tabular}{|lcccc|}
\hline Location & Abbreviation & Date sampled & No. of lobsters & Health status \\
\hline Eastern Long Island Sound, New York & ELIS & April 2001 & 4 & All diseased \\
Buzzards Bay, Massachusetts & BB & May 2002 & 2 & All diseased \\
Central Long Island Sound, New York & CLIS & May 2002 & 3 & All diseased \\
Unknown source, Connecticut & CT & March 2003 & 3 & All diseased \\
Kittery, Maine & ME & Fall 2003 & 15 & 10 diseased, 5 ESD-free \\
Nova Scotia, Canada & CAN & March 2003 & 4 & All ESD-free \\
Gulf of Maine Aquarium, Maine & MEA & May 2008 & 5 & 3 diseased, 2 ESD-free \\
Rhode Island & RI & May 2008 & 3 & All diseased \\
Massachusetts, off shore & MAOS & March 2003 & 3 & 1 diseased, 2 ESD-free \\
\hline
\end{tabular}


seawater, and the carapace was sterilized with $95 \%$ ethanol. The arthrodial space was disinfected with $95 \%$ ethanol, and $2 \mathrm{ml}$ of hemolymph were extracted using a 20-gauge needle and $5 \mathrm{ml}$ syringe by insertion into the hemocoelomic space between the carapace and the first body segment. Sodium dodecyl sulfate was then added to a $2 \%$ concentration and Proteinase $\mathrm{K}$ to a $1.25 \mathrm{mg} \mathrm{ml}^{-1}$ concentration, and the mixture was incubated at $50^{\circ} \mathrm{C}$ for $30 \mathrm{~min}$. Hemolymph samples were then frozen and thawed 3 times at -80 and $50^{\circ} \mathrm{C}$. DNA was extracted using a phenol/ chloroform method. Briefly, phenol (Sigma-Aldrich) was added to lysates at a 1:1 ratio, the mixture was briefly vortexed and then centrifuged at $16000 \times g$ (5 min), and the aqueous phase was removed. A 1:1 volume of chloroform (Fisher Biotech) was added to the aqueous phase, and the mixture was vortexed and spun at $16000 \times g(15 \mathrm{~min})$. DNA was precipitated from this aqueous phase by adding $1 / 10$ volume of $3 \mathrm{M}$ sodium acetate and $2.2 \times$ volume of $100 \%$ cold ethanol. The sample was frozen overnight at $-80^{\circ} \mathrm{C}$ and spun at $16000 \times g(35 \mathrm{~min})$. The DNA pellet was washed with $70 \%$ ethanol, dried, and re-suspended in $200 \mu \mathrm{l}$ of sterile DNAse/RNAse-free ultrapure water (Promega). Finally, this raw DNA was purified using the MoBio PowerClean ${ }^{\mathrm{TM}}$ DNA Clean Up Kit (MoBio Laboratories) according to the manufacturer's instructions.

\section{Nested PCR amplification of 16S rRNA genes}

For DGGE analysis, the variable regions V3, V4, and V5 of the bacterial 16S rRNA genes were amplified in a nested reaction. The first PCR used the primers AC18f (5'-AGA GTT TGA TCH TGG CTY AG-3', Escherichia coli position 8-27 bp) and AC22r (5'-ACG GNT ACC TTG TTA CGA CTT-3', E. coli position 1492-1512 bp). Originally designed by Weisburg et al. (1991), the primers were modified to contain nucleotide ambiguities to allow amplification of broader taxonomic groups. This reaction contained $12.5 \mu \mathrm{l}$ of GoTaq ${ }^{\circledR}$ Green Master Mix (Promega), $2 \mu \mathrm{M}$ of both the forward and reverse primer, and $1.5 \mu \mathrm{l}$ of template DNA in a $25 \mu \mathrm{l}$ reaction. In addition, 1.5 U of DNase I (Qiagen ${ }^{\circledR}$ ) was added to the master mix and ultrapure DNAse/RNAse-free water (Promega) prior to the addition of the template and primers. The first PCR conditions consisted of an initial denaturation step of $95^{\circ} \mathrm{C}$, followed by 20 cycles of $95^{\circ} \mathrm{C}$ for $30 \mathrm{~s}, 55^{\circ} \mathrm{C}$ for $30 \mathrm{~s}$, and $72^{\circ} \mathrm{C}$ for $45 \mathrm{~s}$, and concluded with a final extension step of $72^{\circ} \mathrm{C}$ for $5 \mathrm{~min}$. The nested reaction was prepared using this previous PCR as the template for the primer set 341FGC (Muyzer et al. 1993; 5'-CCT ACG GGD GGC WGC AG-3', E. coli position $341 \mathrm{bp}$ ) and 907R (Muyzer 1999; 5'-CCG YCW ATT CMT TTG AGT TT-3', E. coli position 907). The forward primer was modified by addition of a $40 \mathrm{bp}$ GC-rich sequence (Muyzer et al. 1993). This PCR contained $25 \mu \mathrm{l}$ of $\mathrm{GoTaq}^{\circledR}{ }^{\circledR}$ Green Master Mix, $1.5 \mu \mathrm{M}$ of the forward and $0.5 \mu \mathrm{M}$ of the reverse primers, an additional $1.0 \mathrm{mM} \mathrm{MgCl}_{2}$, and $1.5 \mu \mathrm{l}$ of template in a $50 \mu \mathrm{l}$ reaction volume. This PCR was carried out under a touchdown protocol that consisted of $5 \mathrm{~min}$ at $95^{\circ} \mathrm{C}$, followed by 20 cycles of $1 \mathrm{~min}$ at $95^{\circ} \mathrm{C}, 1 \mathrm{~min}$ at $65^{\circ} \mathrm{C}$ to $55^{\circ} \mathrm{C}$ with a touchdown decrease of $-0.5^{\circ} \mathrm{C} \mathrm{cycle}^{-1}$, and $3 \mathrm{~min}$ at $72^{\circ} \mathrm{C}$, followed by 15 cycles of $1 \mathrm{~min}$ at $95^{\circ} \mathrm{C}, 1 \mathrm{~min}$ at $55^{\circ} \mathrm{C}$, and 3 min at $72^{\circ} \mathrm{C}$, and was concluded with a final extension of 7 min at $72^{\circ} \mathrm{C}$.

\section{DGGE and band processing}

DGGE was carried out using a CBS Scientific DGGE system (CBS Scientific) in $1 \times$ Tris-acetate EDTA buffer, pH 7.8 (Fisher Biotech) at $60^{\circ} \mathrm{C}$. The DGGE gel was $6 \%$ polyacrylamide $(20 \mathrm{~cm} \times 17.6 \mathrm{~cm}$, $1.5 \mathrm{~mm}$ thick) containing an increasing denaturant concentration of 20 to $80 \%$ ( $7 \mathrm{M}$ urea and $40 \%$ formamide was a $100 \%$ denaturant solution). The electrophoresis and band processing was carried out as described by Chistoserdov et al. (2012). Multiple bands were sequenced at identical positions in the gel to verify that they represented the same sequence.

\section{DNA sequencing}

A $1 \mu \mathrm{l}$ aliquot of the aqueous portion of the homogenized acrylamide sample was then taken for reamplification with the primers $341 \mathrm{~F}$ (no GC-clamp) and $907 \mathrm{R}$. This reaction contained $25 \mu \mathrm{l}$ of GoTaq ${ }^{\circledR}$ Green Master Mix, $0.5 \mu \mathrm{M}$ of each forward and reverse primer, and $1.5 \mu \mathrm{l}$ of the DNA sample. The PCR conditions were the same as outlined for primers 341FGC+907R. The PCR product was then purified with a Wizard ${ }^{\circledR}$ SV Gel and PCR CleanUp System (Promega). The purified product was sequenced using the forward primer $341 \mathrm{~F}$ and a BigDye terminator cycle sequencing kit v3.1 and a 3130 Genetic Analyzer (Applied Biosystems).

Sequences were searched against the NCBI GenBank database using the BLASTn tool, and the closest relatives are reported (Benson et al. 2005). Identi- 
fications of bacteria in hemolymph were made based on the BLAST hit with the highest identity and E-value and its associated phylogeny from the Ribosomal Database Project II (RDP originally designed by Larsen et al. 1993). For clarity, sequences are referred to by their RDP phylogeny throughout the text, as the closest hits in GenBank are often phylogenetically inaccurate by sequence name. Some sequences had multiple BLAST hits with high E-values and similar identities. These hits were not identified to the level of species, only to the lowest phylogenetic level that all high-identity BLAST hits belonged to, most often the genus.

\section{RESULTS}

\section{Association of bacterial community with ESD}

All lobsters tested, regardless of whether they showed signs of ESD or were grossly free of signs of ESD, had an observable bacterial community in their hemolymph, except for lobster CT2, which produced a smear in the DGGE gel. This is evidence that all lobsters were bacteremic at the time of sampling no matter their disease state, except for CT2. Four samples produced very low staining intensity, possibly indicating that bacteremia was minimal (Fig. 1). Fig. 1 shows the DGGE profiles from 29 hemolymph samples tested in this study; the remaining samples are from gels that are not shown. Overall, there was a high DGGE profile similarity among all lobsters tested. Thus, there were 7 bands designated as 'common bands' (C1-C7) in the DGGE profiles due to their occurrence in multiple lobsters regardless of disease state or sampling site (Table 2). Two of these bands (C1 and C4) were found in lobsters from all sites (Table 2). Some bands were observed only in diseased lobsters, but these occurred in 6 or fewer individuals and were most often only observed in 1 animal (Table 2). Ten different bands were observed exclusively in hemolymph samples from 1 location, although only in 1 or 2 lobsters.

\section{Bacterial community analysis of lobster hemolymph}

The common band C1 was found in all lobsters with visible profiles and had an RDP phylogenetic affiliation with the Bacteroidetes, Sphingobacteria, Sphingobacteriales, Chitinophagaceae, and belongs to the genus Sediminibacterium. This sequence was
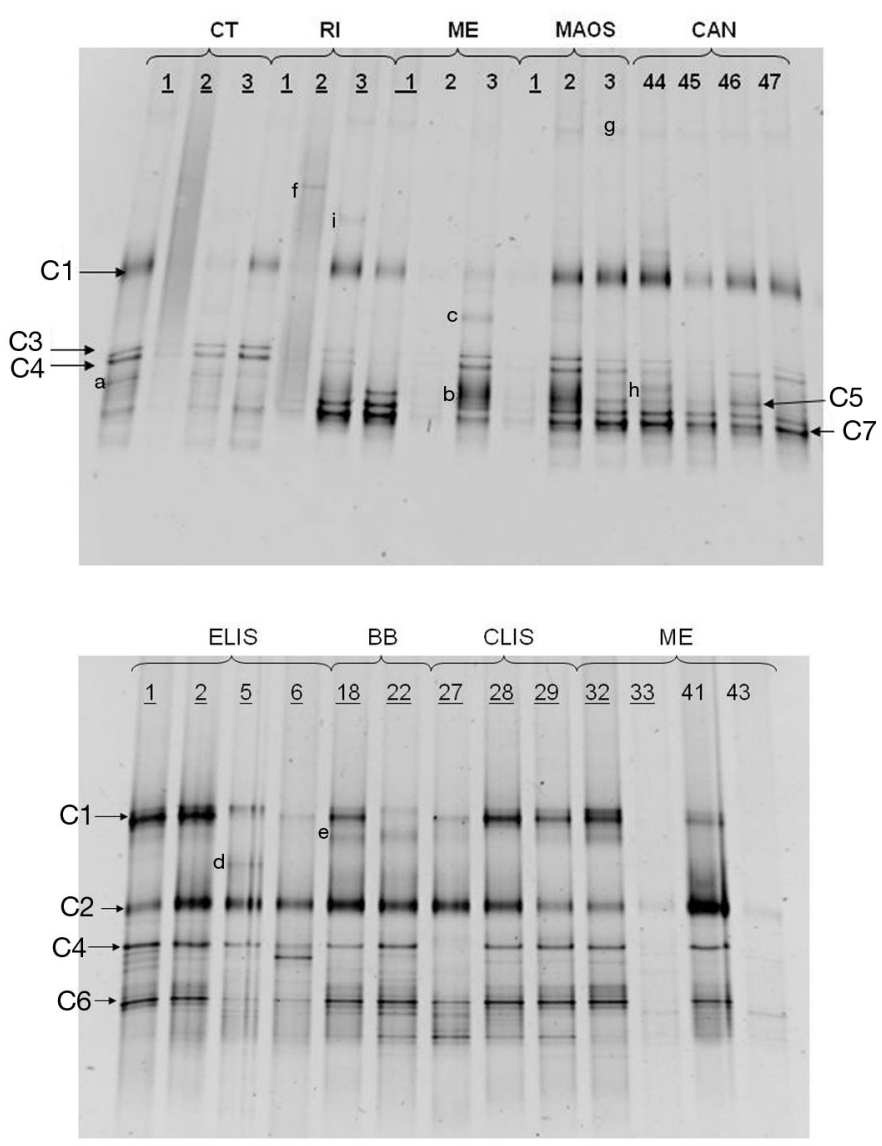

Fig. 1. Homarus americanus. DGGE community profiles of bacteria amplified from hemolymph of lobsters from various locations. Each lane represents an individual lobster and is labeled by location (as given in Table 1) and lobster number. Lobster numbers that are underlined indicate an animal with shell disease, while non-underlined numbers are individuals without signs of shell disease. Common (C1-7) and rare $(\mathrm{a}-\mathrm{i})$ bands are identified (see Table 2 for details)

closely related to a GenBank sequence of a flavobacterial symbiont of the ant Acromyrmex octospinosus and symbionts of the honey bee Apis mellifera (Table 2). Common band C4 was found in 27 lobsters (Fig. 1). This band sequence was identical to $16 \mathrm{~S}$ rRNA from a Ralstonia sp. and highly similar (99\%) to $R$. insidiosa (Table 2) using the RDP. The remaining common bands were not detected in as many samples, but were observed in both ESD-free and diseased individuals and from various locations. Common band C2 (Fig. 1) had a sequence of high similarity to the bacterium Weissella paramesenteroides. The sequence of common band C3 had a phylogenetic affiliation with an uncultured Sphingomonadaceae species and was found in 17 lobsters. The RDP associated this band with genus Novosphingobium. The sequence of common band C5 had 


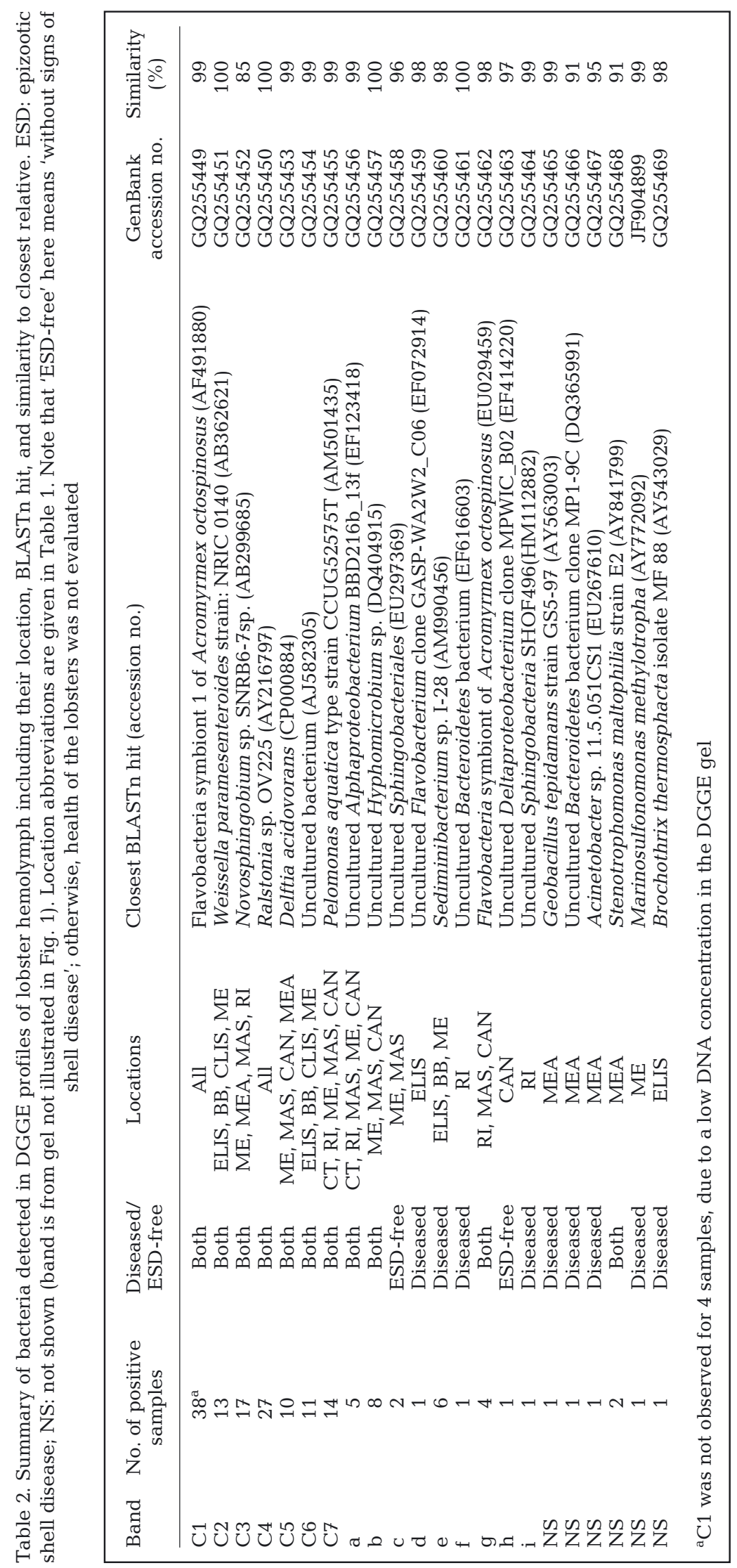

a strong BLAST hit to 16S rRNA of Delftia acidovorans. Band C6 was observed in many of the lobster hemolymph samples, but in all cases the phylogenetic affiliation was poor and it could only be placed in the phylum Firmicutes. According to the RDP database, it appears that this band may represent a member of the order Clostridiales. Common band $\mathrm{C} 7$ was observed in 14 hemolymph DGGE profiles from 5 of the 9 sites. The phylogenetic affiliation of this band was with Burkholderiales, specifically Pelomonas aquatica (Table 2).

A number of bands were unique to individual lobster hemolymph samples or only observed in 6 or fewer individuals. Examples of these rarer bands are identified in Fig. 1 by letter code in successive order according to Table 2. Band ' $\mathrm{e}$ ' was found in 6 diseased lobsters, but not observed in any ESD-free individuals (Fig. 1). A BLAST search of GenBank with the sequence of band ' $\mathrm{e}$ ' provided a hit from a Sediminibacterium sp. (Table 2). Further analysis using the RDP places the sequence of this band in the phylum Bacteroidetes, order Sphingobacteriales, genus Sediminibacterium; however, it is not identical to band C1. Band ' $\mathrm{C}$ ' from an ESD-free lobster from Maine (Fig. 1) had 95\% sequence identity with band ' $\mathrm{e}$ ' and was associated with the genus Flavitalea under the RDP. These 2 bands may represent very closely related bacterial strains. Band ' $a$ ' was found in 5 lobsters and had a phylogenetic affiliation with an uncultured alphaproteobacterium. The RDP database placed this sequence within the family Rhodobacteraceae, but with no specific genus. Band ' $b$ ' was observed in 8 lobsters with an affiliation to an unidentified bacterium using GenBank, but with the RDP database the sequence was placed in Alphaproteobacteria under the genus Hyphomicrobium. Band ' $g$ ' was observed in 4 lobsters from 3 locations and was affiliated with the phylum Bacteroidetes 
and the order Sphingobacteriales. Band ' $g$ ' and common band $\mathrm{C} 1$ had $99 \%$ sequence identity. Therefore, band ' $g$ ' is likely an artifact produced from band $\mathrm{C} 1$ during PCR. A number of bands were only observed in 2 or fewer lobsters. Some were found in both ESD and ESD-free individuals, including a Stenotrophomonas maltophilia related sequence and an uncultured Flavobacteria sequence. Nine bands were observed in the profiles from 1 diseased lobster including various Bacteroidetes, Acinetobacter sp., Marinosulfonomonas methylotropha (identified as 'Thalassobius' sp. by Chistoserdov et al. 2012), Brochothrix thermosphacta, and others.

In some instances, negative controls would produce a faint positive signal after nested PCR. These products were run using DGGE, and consistently, the band sequences represented Delftia acidovorans.

\section{DISCUSSION}

There is little difference between the microbial communities in hemolymph of lobsters with shell disease compared to otherwise ESD-free animals. The community profiles from ESD infected or ESD-free individuals were highly similar, and band C1 (Sediminibacterium sp.) was observed in $90 \%$ of the samples (not detected in samples with poor staining intensity). One sequence related to a different Sediminibacterium sp. (band 'e') was observed in 6 individuals, all of which all showed signs of ESD. This bacterium may be an indicator of the disease, but its low prevalence (6 of 26 diseased lobsters) indicates that it is not likely involved in ESD dissemination or pathogenesis. We found no association between bacteremia and ESD, which supports previous studies using bacterial culture (Chistoserdov et al. 2005, Bartlett et al. 2008). These culture and molecular based studies verify the notion proposed by Chistoserdov et al. (2005) that ESD is a strictly dermal disease. While the disease is readily observable grossly as lesions of the carapace, it is not reflected in the internal microbiology.

PCR-DGGE of hemolymph samples in this study detected bacteremia in all lobsters tested, except for 1 animal which produced a smear in DGGE. This high level of bacteremia is similar to the recent culture-based analysis of Bartlett et al. (2008), who found that bacteremia was as high as $88 \%$ in lobsters from Western Long Island Sound, but there were much lower levels for the other 2 sampling sites. Another study of bacteriological culture of hemolymph from lobsters with ESD reported a prevalence of $24 \%$ bacteremia $(n=29)$ (Chistoserdov et al. 2005). Historically, bacteria have been routinely isolated from hemolymph of the American lobster (Rabin 1965, Stewart et al. 1966, Bowser et al. 1981, Chistoserdov et al. 2005, Bartlett et al. 2008); however, levels of bacteremia at the population level has varied greatly. These discrepancies may be due to the bias of culture-based microbial community analysis, where it is estimated that less than $1 \%$ of environmental bacteria are amenable to culture (Muyzer 1999). The high levels of bacteremia detected in this study is likely due to the high sensitivity of nested PCR, which is estimated to be able to amplify as low as 5 colony-forming units (CFU) $\mathrm{ml}^{-1}$ in natural samples or 10 fg of DNA (Llop et al. 2000, Möbius et al. 2008).

Some of the bacteria identified in this study have been isolated in culture-based studies of lobster hemolymph, including Stenotrophomonas maltophilia and Brochothrix thermosphacta (Chistoserdov et al. 2005, Bartlett et al. 2008). Outside of these few correspondences, the bacterial groups and species found using PCR-DGGE varied greatly from the cultured communities reported in the literature. Bartlett et al. (2008) cultured a large amount of Grampositive bacteria including Staphylococcus spp., Enterococcus spp., and Streptococcus-like organisms. In our study, however, the bacterial communities were predominantly Gram-negative. This discrepancy is likely due to the conceptual differences in community analysis techniques. Any culturebased technique is inherently biased to less fastidious microbes that may represent small components of natural communities. Furthermore, the identification techniques used by Bartlett et al. (2008) were based upon biochemical data that were compared to known databases that are biased to mostly pathogenic bacteria of human and veterinary importance.

Marinosulfonomonas methylotropha (analogous to 'Thalassobius' sp. from Chistoserdov et al. 2012), detected in 1 sample was identified in ESD lesions using PCR-DGGE. It is possible that this bacterium had penetrated through the ESD lesion into the hemolymph, or there was cross-contamination with hemolymph during sampling. A number of BaCteroidetes were previously cultured from the lesions of lobsters with ESD, such as Aquimarina 'homaria,' A. muelleri, and Cellulophaga baltica, but none of these was detected in this study. Thus, there was no evidence, outside of $M$. methylotropha, that bacteria present in ESD lesions can penetrate the carapace and grow in the lobster hemolymph; this may, however, depend on whether lesions become so severe as 
to ulcerate and remove the internal/cuticular barrier.

Some bacterial species were identified in a high proportion of hemolymph samples regardless of locations or disease state. Band C1 was observed in $90 \%$ of lobsters tested. The sequence of C1 (Sediminibacterium sp.) was highly similar to the sequence of a reported flavobacterial symbiont of the ant Acromyrmex octospinosus and a symbiont of the honey bee Apis mellifera (Martinson et al. 2011). Due to its ubiquity within the lobsters tested in this study, it is possible that this bacterium is a symbiont related to that found in the insects. The band representing Ralstonia sp. found in $64 \%$ of the tested lobsters may also exist in some sort of mutualistic relationship within the lobster organism. Symbionts of arthropods have been well described in the literature, including endosymbionts (Cochran 1985, van Borm et al. 2002). Endosymbiotic bacteria in the hepatopancreas of marine and terrestrial isopod species have been identified using DGGE, including members of the genera Burkholderia, Aeromonas, Rhodobacter, Pseudomonas, uncultured Gammaproteobacteria, and various yeasts (Wang et al. 2007). Interestingly, a Ralstonia sp. and a Burkholderia sp. were detected from the gut communities of the Norway lobster Nephrops norvegicus using culture-independent techniques (Meziti et al. 2010), indicating that perhaps some bacteria in lobster hemolymph are entering from the gut. Our study has demonstrated that future investigations of the role of bacteria in lobster hemolymph outside of a pathological context is warranted.

Some bacteria detected in multiple samples in this study are suspected contaminants due to the easy carryover of DNA from PCR reactions or from human and laboratory sources, particularly when using the highly sensitive nested PCR (Silkie et al. 2008). Two suspected contaminants are Weisella paramesenteroides and Delftia acidovorans. W. paramesenteroides has been identified as a common inhabitant of human skin (Grice et al. 2009), and D. acidovorans was detected in DGGE of high PCR cycle negative controls (not shown), indicating that it is likely a reagent contaminant. This bacterium has been identified as a reagent contaminant previously (Woyke et al. 2010), and its DNA can be easily amplified in low copy number templates such as lobster hemolymph. Gomila et al. (2007) and Ryan et al. (2011) have shown respectively that Pelomonas aquatica and Ralstonia insidiosa can be associated with industrial and high purity water. We went to great lengths to remove contaminating DNA from the water used in this study, including use of DNase and UV treatment; thus, it is unlikely that contaminating bacteria detected here are from the high purity water. We also ran double-negative controls with nested PCR reactions (i.e. a nested PCR of the first negative PCR reaction) and 'mock' DNA isolation, essentially trying to isolate DNA from the components and reagent used for DNA isolation from lobster hemolymph. D. acidovorans DNA was the only contaminating DNA which we could detect. Its source is more likely PCR master mixes from which DNA cannot be removed because of the sensitivity of reaction components. It is worth noting that both $P$. aquatica and $R$. insidiosa are ubiquitous and tend to be associated with living organisms including humans (e.g. Gomila et al. 2007, Ryan et al. 2011) and that Ralstonia sp. has been found in an independent study to be associated with the Norway lobster (Meziti et al. 2010).

Evidence from this and previous work indicates that ESD is not associated with internal infection by any specific bacterial species. These data support the notion the ESD is a truly dermal disease and does not develop due to an internal bacterial pathogen. While bacteria are commonly encountered in hemolymph of the American lobster, they are not associated with ESD and are generally not from the same phylogenetic groups found in the lesions.

Acknowledgements. Donations of lobsters for this research by B. Estrella (Massachusetts Division of Marine Fisheries), P. Howell (Connecticut DEP), D. Kaselouskas (Maine lobster fisherman), C. LoBue (New York DEC, presently at the Nature Conservancy), and C. Wilson (Maine Department of Marine Resources) are greatly appreciated. This work was supported by the National Marine Fisheries Service as the 'New England Lobster Research Initiative: Lobster Shell Disease' under NOAA contract NA06NMF4720100 to the University of Rhode Island Fisheries Center and by the National Sea Grant College Program of NOAA under award NA16RG1354 to A.Y.C. and R.S. The views expressed herein are those of the authors and do not necessarily reflect the views of NOAA or any of its sub-agencies. The US Government is authorized to produce and distribute reprints for government purposes, notwithstanding any copyright notation that may appear hereon.

\section{LITERATURE CITED}

Bartlett SL, Wooster GA, Sokolowski MS, Dove AD, Bowser PR (2008) Naturally occurring bacteraemia in American lobsters, Homarus americanus Milne-Edwards, in Long Island Sound. J Fish Dis 31:19-25

Benson DA, Karsche-Mizrachi I, Lipman DJ, Ostell J, Wheeler DL (2005) GenBank. Nucleic Acids Res 33: D34-D38

Bowser PR, Rosemark R, Reine CR (1981) A preliminary report of vibriosis in cultured American lobsters Homarus americanus. J Invertebr Pathol 37:80-85 
Castro KM, Angell TE (2000) Prevalence and progression of shell disease in American lobster, Homarus americanus, from Rhode Island waters and the offshore canyons. J Shellfish Res 19:691-700

Chistoserdov A, Mirasol F, Smolowitz R (2002) Characterization of microbial assemblages involved in the development of shell disease in the American lobster, Homarus americanus. J Shellfish Res 21:410

Chistoserdov AY, Smolowitz R, Mirasol F, Hsu A (2005) Culture-dependent characterization of the microbial community associated with epizootic shell disease lesions in American lobster, Homarus americanus. J Shellfish Res 24:741-747

Chistoserdov AY, Quinn RA, Gubbala S, Smolowitz R (2012) Bacterial communities associated with lesions of shell disease in the American lobster, Homarus americanus, Milne-Edwards. J Shellfish Res 31:449-462

Cobb JS, Castro KM (2006) Shell disease in lobsters: a synthesis. Rhode Island Sea Grant, Narragansett, RI

> Cochran DG (1985) Nitrogen excretion in cockroaches. Annu Rev Entomol 30:29-49

Gomila M, Bowien B, Falsen E, Moore ER, Lalucat J (2007) Description of Pelomonas aquatica sp. nov. and Pelomonas puraquae sp. nov., isolated from industrial and haemodialysis water. Int J Syst Evol Microbiol 57:2629-2635

Grice E, Kong H, Conlan S, Deming C and others (2009) Topographical and temporal diversity of the human skin microbiome. Science 324:1190-1192

Larsen N, Olsen GJ, Maidak BL, McCaughey MJ and others (1993) The ribosomal database project. Nucleic Acids Res 21:3021-3023

Llop P, Bonaterra A, Penalver J, Lopez MM (2000) Development of a highly sensitive nested-PCR procedure using a single closed tube for detection of Erwinia amylovora in asymptomatic plant material. Appl Environ Microbiol 66: 2071-2078

Martinson VG, Danforth BN, Minckley RL, Rueppell O, Tingek S, Moran NA (2011) A simple and distinctive microbiota associated with honey bees and bumblebees. Mol Ecol 20:619-628

Meziti A, Ramette A, Mente E, Kormas KA (2010) Temporal shifts of the Norway lobster (Nephrops norvegicus) gut bacterial communities. FEMS Microbiol Ecol 74:472-484

Möbius P, Hotzel H, Rabbach A, Kohler H (2008) Comparison of 13 single-round and nested PCR assays targeting IS900, ISMav2, f57 and locus 255 for detection of Mycobacterium avium subsp. paratuberculosis. Vet Microbiol 126:324-333

Muyzer G (1999) DGGE/TGGE a method for identifying

Editorial responsibility: Grant Stentiford,

Weymouth, UK genes from natural ecosystems. Curr Opin Microbiol 2: 317-322

Muyzer G, de Wall EC, Uitterlinden AG (1993) Profiling of complex microbial populations by denaturing gradient gel electrophoresis analysis of polymerase chain reaction amplified genes coding for the 16s rRNA. Appl Environ Microbiol 59:695-700

Muyzer G, Brinkhoff T, Nubel U, Santegoeds C, Schafer H, Wawer C (1998) Denaturing gradient gel electrophoresis (DGGE) in microbial ecology. In: Akkermans ADL, van Elsas JD, de Bruijn FJ (eds) Molecular microbial ecology manual 3.4.4. Kluwer Academic Publishers, Dordrecht, p 1-27

Quinn RA, Metzler A, Smolowitz R, Tlusty M, Chistoserdov AY (2012) Exposure of Homarus americanus shell to three bacteria isolated from naturally occurring epizootic shell disease lesions. J Shellfish Res 31:485-493

Rabin H (1965) Studies on gaffkemia, a bacterial disease of the American lobster, Homarus americanus (MilneEdwards). J Invertebr Pathol 7:391-397

Ryan MP, Pembroke JT, Adley CC (2011) Genotypic and phenotypic diversity of Ralstonia pickettii and Ralstonia insidiosa isolates from clinical and environmental sources including high-purity water. Diversity in Ralstonia pickettii. BMC Microbiol 11:194

Silkie SS, Tolcher MP, Nelson KL (2008) Reagent decontamination to eliminate false-positives in Escherichia coli qPCR. J Microbiol Methods 72:275-282

Smolowitz R, Chistoserdov AY, Hsu A (2005) A description of the pathology of epizootic shell disease in the American lobster, Homarus americanus. J Shellfish Res 24: 749-756

Stewart JE, Cornick JW, Spears DI, McLeese DW (1966) Incidence of Gaffkya homari in natural lobster (Homarus americanus) populations of the Atlantic region of Canada. J Fish Res Board Can 23:1325-1330

van Borm S, Buschinger A, Boomsma JJ, Billen J (2002) Tetraponera ants have gut symbionts related to nitrogenfixing root-nodule bacteria. Proc R Soc Lond B Biol Sci 269:2023-2027

Wang Y, Brune A, Zimmer M (2007) Bacterial symbionts in the hepatopancreas of isopods: diversity and environmental transmission. FEMS Microbiol Ecol 61:141-152

Weisburg WG, Barns SM, Pelletier DA, Lane DL (1991) 16S ribosomal DNA amplification for phylogenetic study. J Bacteriol 173:697-703

Woyke T, Damon T, Mavromatis K, Clum A and others (2010) One bacterial cell, one complete genome. PLoS ONE 5:e10314

Submitted: April 19, 2012; Accepted: November 30, 2012 Proofs received from author(s): March 8, 2013 